\title{
Investigation of the Sensitivity of Mycobacterium tuberculosis Strains Isolated from Various Clinical Samples in Eastern Turkey to Major Anti-tuberculosis Drugs
}

\author{
Türkiyenin Doğusunda Çeşitli Klinik Örneklerden İzole Edilen \\ Mycobacterium tuberculosis Suşlarinin Major Anti-Tüberküloz \\ Illaçlara Duyarlılıklarının Araştırılması
}

\author{
(DAhmet Yılmaz', @Dursun Erol Afşin² \\ 'Department of Medical Laboratory Techniques, Erzurum Vocational School of Health, Ataturk University, Erzurum, Turkey \\ ${ }^{2}$ Health Sciences University, Erzurum Regional Training and Research Hospital, Department of Pulmonary Diseases, Erzurum, Turkey
}

\begin{abstract}
Objective: In the study, 419 Mycobacterium tuberculosis complex strains, which were isolated from samples sent to the Regional Tuberculosis Laboratory in our city between 2015 and 2019 with suspected tuberculosis from Erzurum and surrounding cities were investigated.
\end{abstract}

Material and Method: Our research is a retrospective crosssectional study and clinical samples sent to the Regional Public Health Laboratory with suspicion of Tuberculosis within a five-year period from January 2015 to December 2019 were first evaluated by using Ehrlich-Ziehl-Neelsen staining technique. The samples were then simultaneously inoculated into the automated culture system (BACTEC MGIT 960) with Löwenstein-Jensen medium. Sensitivity research was conducted for isoniazide (INH), rifampicin (RIF), streptomycin (STM) and ethambutol (ETM) antibiotics with BACTEC MGIT 960 system to samples defined by M. tuberculosis complex strains identification test (TBC ID) from reproduction positive tubes.

Results: In our study, 337 (80.4\%) of the 419 M. tuberculosis complex strains investigated in our study were susceptible to all major anti-TB drugs, while 82 (19.6\%) were found to be resistant to at least one major anti-TB drug. The distribution of resistance ratios was INH (11.9\%), STM (11.7\%), RIF (4.1\%), ETM (3.6\%). Multi-drug resistant (MDR)-TB ratio (IZN+ RIF) was found to be (3.6\%).

Conclusions: In our study, in the strains in which resistance to anti-TB drugs was investigated, the highest drug resistance was determined for IZN. The lowest drug resistance was determined for ETM.

Keywords: Mycobacterium tuberculosis, drug resistance, multiple drug resistant (MDR) tuberculosis, anti-tuberculosis drugs

\section{Öz}

Amaç: Çalışmada ilimizde bulunan Bölge Tüberküloz Laboratuvarı́na 2015-2019 yılları arasında Erzurum ve çevre illerden tüberküloz şüphesi ile gönderilen örneklerden izole edilmiş olan 419 Mycobacterium tuberculosis kompleks suşun, major anti-tuberküloz ilaçlara karşı direnç durumu araştıııldı.

Gereç ve Yöntem: Araştırmamız retrospektif kesitsel bir çalışma olup, Ocak 2015-Aralık 2019 tarihleri arası beş yıllık sürede Bölge Halk Sağlığı Laboratuvarına Tüberküloz şüphesiyle gönderilen klinik örnekler, ilk önce Ehrlich-Ziehl-Neelsen boyama yöntemi kullanılarak değerlendirildi. Daha sonra örnekler eş zamanlı olarak Löwenstein-Jensen besiyeri ile otomatize kültür sistemine (BACTEC MGIT 960) ekimleri yapıldı. Üremesi pozitif tüplerden identifikasyon testi (TBC ID) ile $\boldsymbol{M}$. tuberculosis kompleks suşu tanımlaması yapılan örneklere BACTEC MGIT 960 sistemi ile izoniazid (INH), rifampisin (RIF), streptomisin (STM) ve etambutol (ETM) antibiyotikleri için duyarlıık araştırması yapıldı.

Bulgular: Çalışmamızda ilaç duyarlılığı araştırılan 419 M. tuberculosis kompleks suş'un 337'si $(\% 80,4)$ majör anti-TB ilaçların tümüne duyarlı iken 82'si $(\% 19,6)$ en az bir majör anti-TB ilaca dirençli bulundu. Direnç oranlarının dağııımı IZN $(\% 11,9)$, STM $(\% 11,7)$, RIF $(\% 4,1)$, ETM $(\% 3,6)$ idi. Çoklu ilaca dirençli (ÇID)-TB oranı (INH +RIF) $(\% 3,6)$ olarak bulundu.

Sonuç: Çalışmamızda majör anti-TB ilaçlara karşı direnç araştırılan suşlarda en yüksek ilaç direnci IZN için belirlendi. En düşük ilaç direnci ETM için saptandı.

Anahtar Kelimeler: Mycobacterium tuberculosis, ilaç direnci, çoklu ilaç dirençli (ÇiD) tüberküloz, anti-tuberküloz ilaçlar

Corresponding (iletişim): Ahmet Yilmaz, Department of Medical Laboratory Techniques, Erzurum Vocational School of Health, Ataturk University 25240, Erzurum, Turkey

E-mail (E-posta): aymet25@hotmail.com

Received (Geliş Tarihi): 16.12.2020 Accepted (Kabul Tarihi): 23.12.2020 


\section{INTRODUCTION}

Tuberculosis (TB) caused by M. tuberculosis is a disease that causes the deaths of more than 1 million people each year in mostly low-income and middle-income countries. ${ }^{[1,2]}$ TB remains one of the top 10 causes of deaths worldwide. Millions of people continue to fall ill from TB every year. [3] There has been a significant decrease in the registered incidence of tuberculosis in Turkey in recent years. As such, while in 2005 the incidence ratio was 29.4 per hundred thousand in 20,535 registered patients, it decreased to 14.6 per hundred thousand in 2017. ${ }^{[4]}$ In our country, out of the 12,046 total number of patients diagnosed with TB in 2017, 92.2\% were new cases; $7.8 \%$ were previously treated cases; $42.3 \%$ were female; $57.7 \%$ were male; $66.1 \%$ were patients with pulmonary involvement; $33.9 \%$ were patients with extrapulmonary involvement. ${ }^{[4]}$

The treatment of tuberculosis with drugs began towards the end of the 1940s and over time resistance developed against the drugs used in this treatment. Resistance to anti-TB drugs is an important problem. ${ }^{[5]}$ The drug-resistant TB (DRTB) problem which has attracted attention especially since the early 1990s, has reached a global dimension today. The increase, especially in multi-drug resistant (MDR) TB cases, is the most important problem that threatens the success of TB control programs. ${ }^{[6]}$ While drug resistance can develop spontaneously in a drug-sensitive strain before treatment, MDR-TB could also develop despite the fact that the primary treatment is completed. ${ }^{[7,8]}$ MDR-TB is defined as TB resistant to caused by $M$. tuberculosis complex isolates resistant to $\mathrm{INH}$ and RIF which are among the primary (first-line) antiTB drugs. ${ }^{[9,10]}$ In our country, the number of MDR-TB in 2017 patients was 191. In 2015, the treatment success for MDR-TB patients at the $24^{\text {th }}$ month 2015 was $67.8 \% \cdot{ }^{[4]}$ The American Thoracic Society and the Center for Disease Control and Prevention (CDC) recommend susceptibility tests for at least first step anti-TB drugs in all older and new TB cases to ensure that patients with TB can be treated correctly and prevent the development of resistance to anti-TB drugs. ${ }^{[6]}$

In this study, resistance to INH, RIF, STM and ETM of $419 \mathrm{M}$. tuberculosis isolates isolated from different clinical specimens with suspected tuberculosis from 11 provinces in Erzurum and its surrounding were investigated.

\section{MATERIAL AND METHOD}

In our research, sensitivity results for STM, INH, ETM, RIF against major drugs used in TB treatment in 419 Mycobacterium tuberculosis complex strains isolated from patient clinical samples sent to the Regional Public Health Laboratory with pre-TB diagnosis between 2015 and 2019 from 13 cities, mainly from cities in eastern Anatolia region were investigated. All operations in the laboratory were performed in Class II biosafety cabins using the necessary protective personal equipment such as gloves, glasses and protective clothing. If different clinical samples had been sent for a patient, only one strain isolated from among these samples was included in the study. Multiple antibiotic sensitivity tests were performed for a patient in one year and if the MDR- M. tuberculosis complex strain was not defined in subsequent clinical samples, the first result was included in the study. Whether the patients who participated in the study had previously used anti-TB drugs, could not be definitively revealed because of the changes in our hospital automation systems at different times and the shortcomings in patient records.

Pleural fluid and Cerebrospinal fluid (CSF) samples coming to the laboratory which were thought to have been obtained in aseptic conditions, were processed directly without being decontaminated; while clinical samples such as sputum, abscess, bronchial lavage were processed after homogenization and decontamination using $\mathrm{N}$-acetyl-Lcysteine and sodium hydroxide (NALC and $\mathrm{NaOH}$ ). Then the $\mathrm{pH}$ of the clinical sample was adjusted, and it was centrifuged and intensified. The resulting sediment was simultaneously inoculated in $0.5 \mathrm{ml} \mathrm{MGIT}$ tubes (Becton Dickinson Diagnostics, USA), which contain Middlebrook 7H9 liquid medium used simultaneously in both the Löwenstein-Jensen classical culture medium and BACTEC MGIT 960 full automatic systems. 0.8 ml PANTA (polymyxin B, amphotericin $B$, nalidixic acid, trimethoprim, azlocillin) was added to MGIT tubes before inoculation.

All samples where inoculation was done were left for incubation for 42 days. Acid resistant staining was made in samples that gave positive results. BD MGIT-TBC Identification Test (TBC ID) (Becton Dickinson Diagnostics, USA) detecting MPT64 antigen was administered in accordance with the recommendations of the manufacturer. Sensitivity/resistance to major anti-TB drugs of the strains evaluated as M. tuberculosis complex strain was investigated in accordance with the manufacturer's operating procedure using BACTEC MGIT 960 system to be the final concentration of the drug being ETM $(5.0 \mu \mathrm{g} / \mathrm{ml})$, INH $(0.1 \mu \mathrm{g} / \mathrm{ml})$, RIF $(1.0$ $\mu \mathrm{g} / \mathrm{ml})$, and STM $(1.0 \mu \mathrm{g} / \mathrm{ml})$.

In addition to using H37Rv reference strain (ATCC 35838) during the laboratory internal quality control process where the research was carried out, our laboratory is also included in the external quality program of the Turkish Public Health Laboratory of the Ministry of Health. This research was approved by the "Atatürk University Faculty of Medicine Ethics Board of Clinical Research of " by decree no. 19 on 13.02.2019.

\section{Statistical Analysis}

In the analysis of the data used in the study the 22.0 IBM SPSS package program was used. The frequency and percentages of the data was calculated. When evaluating the results of categorical data in our research, A p-value equal or less than $0.05(\leq 0.05)$ is consiredered statistically significant. 


\section{RESULT}

A total of 419 strains isolated from Erzurum, Ağrı, Erzincan, Kars, Batman, Mardin, Siirt, Rize, Ardahan, Giresun, Bayburt and Iğdır cities were included in the study between January 2015 and December 2019. The strains were isolated from various clinical materials in the tuberculosis unit of Erzurum Regional Public Health Laboratory. The distribution of clinical samples included in this study are also shown in Table 1. It was observed that 259 (61.8\%) of patients from whom $M$. tuberculosis complex strain was isolated were male and 160 (38.2\%) were female. The distribution of strains taken by year consisted of 61 strains in 2015, 62 in 2016, 106 in 2017, 113 in 2018 and 77 in 2019.

Resistance ratios of strains isolated using BACTEC MGIT 960 method against anti-tuberculosis (anti-TB) drugs are shown in Table 2 according to gender. 337 (80.4\%) of the strains were susceptible to all major anti-TB drugs, while 82 (19.6\%) were found to be resistant to at least one major anti-TB drug. The highest resistance ratio was found to be $11.9 \%$ against $\mathrm{INH}$, while the lowest resistance ratio was determined to be $3.6 \%$ against ETM antibiotics (Figure 1). Resistance to STM was $11.7 \%$, resistance to RIF was $4.1 \%$ (Figure 1 ). In our study, while there was single resistance in $51(12.2 \%)$ of the isolates, in $31(7.4 \%)$ of the isolates there was resistance to two or more of the tested drugs (Table 3). MDR-TB ratio (IZN+RIF) has been determined 15 (3.6\%) isolates. In this study $6(1.4 \%)$ isolates resistant to all four of the antibiotics (IZN+RIF+ETM+STM) were identified. M. tuberculosis isolate were found in $200(47.7 \%)$ of all 419 specimens submitted for microscopy.
Table 1. Samples from which Mycobacterium tuberculosis complex strain was isolated

Patient sample

Sputum

Broncho alveolar lavage

Aspiration material

Pleural Fluid

Biopsy

Peritoneal fluid

Total Number (n)

Percentage (\%)

$\begin{array}{cc}352 & 84 \\ 37 & 8.8 \\ 15 & 3.6 \\ 11 & 2.6 \\ 3 & 0.7 \\ 1 & 0.2 \\ 419 & 100\end{array}$

Table 2. State of resistance to antibiotics depending on gender status

\begin{tabular}{lccc}
\multirow{2}{*}{ Characteristic } & \multicolumn{2}{c}{ Antibiotic Resistance Positive } & \multirow{2}{*}{ P value } \\
\cline { 2 - 3 } & Number $(\mathbf{n})$ & Percentage (\%) & \\
\hline Gender & & & \\
Male $(\mathrm{n}=259)$ & 56 & 21.6 & 0.206 \\
Female $(\mathrm{n}=160)$ & 26 & 16.3 & \\
Total & 82 & 19.6 & \\
\hline
\end{tabular}

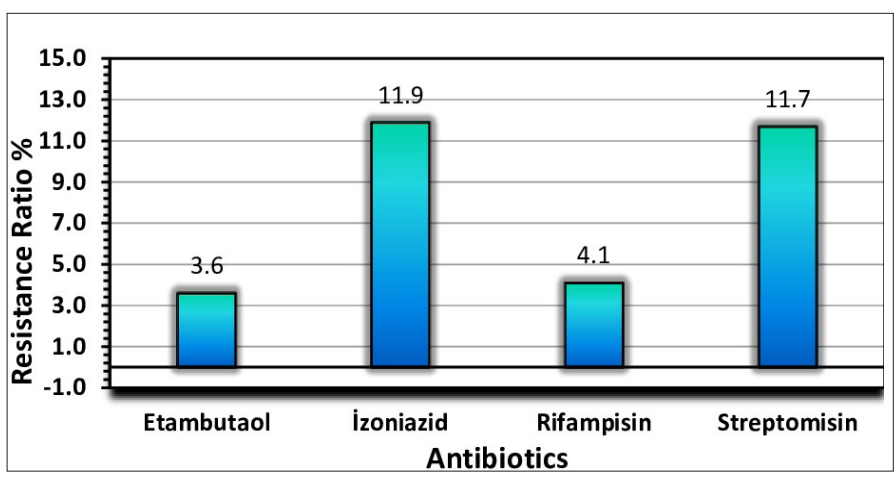

Figure 1. Resistance ratios against major anti-tuberculosis drugs

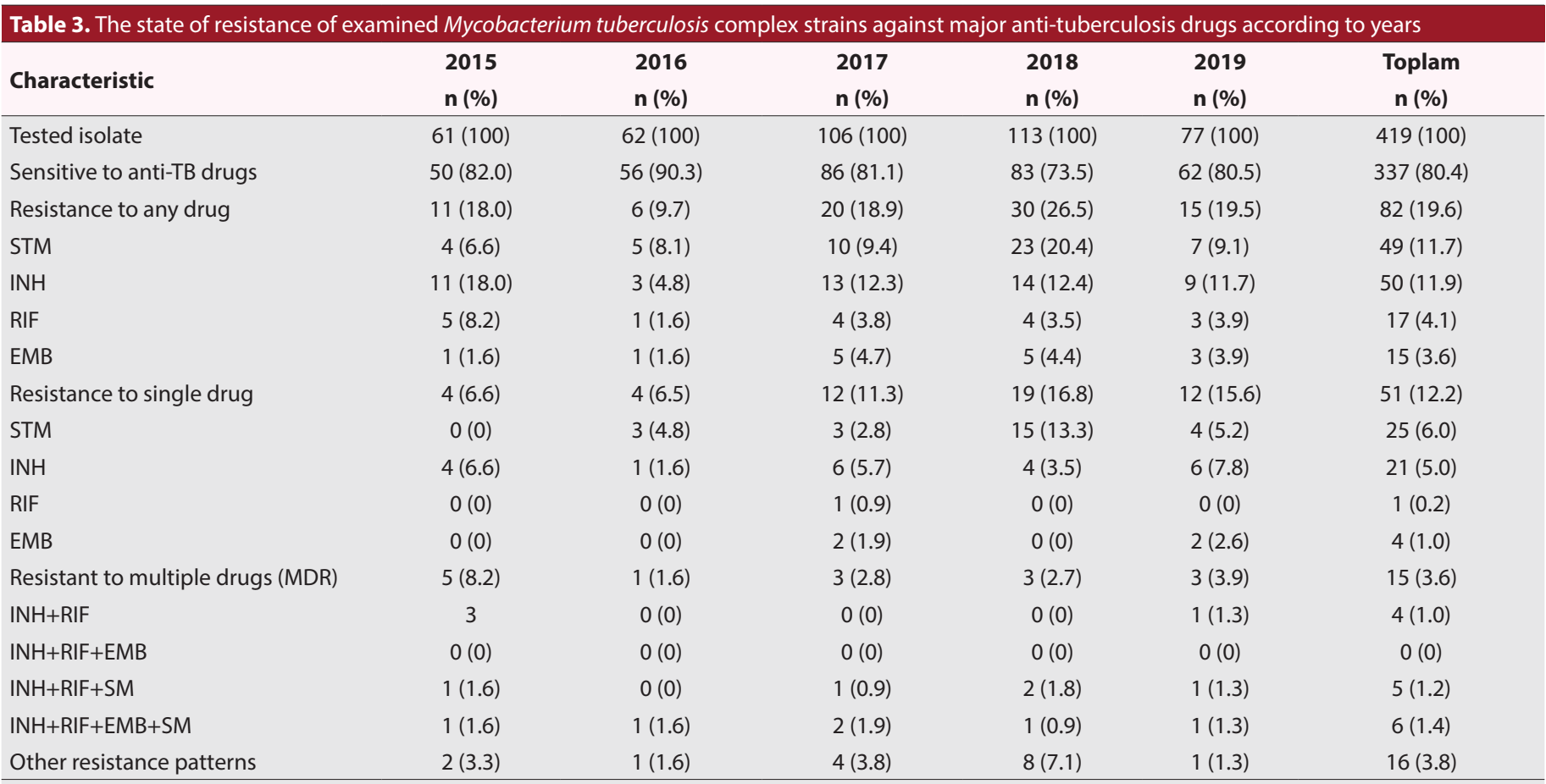




\section{DISCUSSION}

Epidemiological data and lab data are important in terms of evaluating achievements in the fight against tuberculosis, obtaining healthy data and determining real resistance ratios. The data obtained in our study is important for regional evaluation as it includes Erzurum city and surrounding cities. When we look at the resistance ratios of at least one anti-TB drug in some studies conducted in Turkey and around the world; Esenkaya Taşbent et al. ${ }^{[11]}$ found resistance to at least one major drug in $16.9 \%$ of patients. In the study by Burak Selek et al. ${ }^{[12]} 27.8 \%$ of the isolates obtained from patients were found to be resistant to at least one antibiotic. In their study, Artan et al. ${ }^{[9]}$ reported that, $25.5 \%$ of the strains isolated from older and new TB patients were resistant to at least one of the anti-TB drugs. In Ethiopia, Adene et al. ${ }^{[13]}$ found $20.2 \%$ resistance to any primary anti-TB drug. In Korea, $19.4 \%$ of isolates taken from patients in Lee et al. ${ }^{[14]}$ study group. Were shown to be resistant to any one of the anti-TB drugs. In He et al. ${ }^{[15]}$ study in China, the resistance rate against at least the first step drug was $21.2 \%$. According to the results of our study, the resistance rate against any major anti-TB drug was 19.6\%.

In the "Tuberculosis War in Turkey 2018 Report" published by the Ministry of Health in Turkey, resistance ratios against major anti-TB drugs in 2009-2016 were reported to be $11.9-15.4 \%$ for INH; $4.2-6.8 \%$ for RIF; 3.7\% to 5.4\% for EMB; $8.5 \%-11.3 \%$ for STM. The first option with the highest resistance ratio in this data is the anti-TB drug INH. ${ }^{[16]}$ In a study conducted by Maurya et al. in India, anti-TB resistance ratios were reported as $27.6 \%$ for INH, $14.6 \%$ for RIF, \%14.6 for ETM, 13,8 for SM; In China, Chang et al. ${ }^{[18]}$ reported resistance ratios of $11.7 \%$ for $\mathrm{INH}, 2.8 \%$ for RIF, 2.5\% for ETM, 11.1\% for STM; in Korea Lee et al.[14] found total resistance ratios of $15.5 \%$ for $\mathrm{INH}, 9.3 \%$ for $\mathrm{RIF}, 6.7 \%$ for ETM, 5.4\% for STM in old and new cases. Previously in Erzurum, Aktaş et al. ${ }^{[19]}$ found resistance ratios of $16.7 \%$ for $\mathrm{INH}, 10 \%$ for RIF, $11.7 \%$ for STM, $8.3 \%$ for EMB against primary anti-TB drugs in their study which investigated the profile of resistance to drugs in two different ways using the by MGIT method. In our study, the average resistance ratios for five years in isolated strains were determined as $11.9 \%$ for INH, $4.1 \%$ for RIF, $11.7 \%$ for STM and 3.6\% for EMB. MDR-TB rate was found to be $3.6 \%$. In our study, the highest resistance among major anti-TB drugs was determined for INH, the second highest resistance was found for SM, and the lowest resistance rate was found for EMB antibiotics. The results we obtain are compatible with the Turkish data. According to the previous study of Aktaş et al.. ${ }^{[19]}$ there has been a decrease in resistance ratios against other antibiotics, excluding resistance to STM.

In many studies conducted around the world outside Turkey, it also was observed that the most common resistance in M. tuberculosis complex strain was against INH. Such high resistance to INH and STM is due to the widespread use of this drug in prophylaxis and treatment. It is also assessed that the widespread use of streptomycin for non-TB reasons may be one of the reasons for the high resistance ratio against this drug. ${ }^{[15]}$ We see some differences in the results of the studies carried out in Turkey and in different parts of the world. We think these differences stem from the characteristics of the patient population, their adaptation to treatment and regional differences. However, although there is no homogeneous distribution of resistance ratios between countries or in different parts of the same country, we can say that we are facing a serious resistance problem for tuberculosis.

In the "Tuberculosis War in Turkey 2018 Report ", the MDR TB rate was reported as $3.3-5.4 \%$ in $2009-2016 .{ }^{[16]}$ In the studies on MDR tuberculosis worldwide, quite different MDRMycobacterium tuberculosis complex strain resistance ratios have been reported. In Japan Hattori et al. ${ }^{[20]}$ reported a very low ratio of $0.2 \%$ in their study; in Indonesia, Lisdawati et al. ${ }^{[21]}$ reported MDR- M. tuberculosis complex strain rate as $5.4 \%$, in their study; in Ethiopia, Solomon et al. ${ }^{[22]}$ reported a MDR rate of $2.27 \%$ in society, while the MDR rate for inmates living in prison was $15.89 \%$; in China, He et al. ${ }^{[15]}$ reported a MDR- $M$. tuberculosis complex strain ratio of $6.2 \%$. In a well-attended study; while in Pakistan Akhtar et al. ${ }^{[23]}$ reported a quite high resistance ratio of $69 \%$ in their study.

In our study, the resistance against MDR- M. tuberculosis complex strain was $3.6 \%$, and our results were within the Turkish average. However, an increase in MDR drug resistance rates was observed in Erzurum compared to the results of the previous study by Ozmen et al. ${ }^{[24]}$ MDR-TB cases in TB treatment prolong the duration of treatment and reduce the success of treatment. Therefore, the detection of MDRTB cases in a short time and treating them with appropriate drugs will contribute to the control of TB disease by breaking the chain of transmission. The development of resistance to RIF alone in patients is rarely seen. ${ }^{[6]}$ In our study, RIF resistance alone was detected in only one patient $(0.2 \%)$ over a five-year period. In addition, resistance to all major anti-TB drugs was observed in 6 strains.

There were some limitations to this study. The laboratory we first studied started to serve in 2014 and the study was done on clinical samples sent from hospitals in different cities. For this reason, limited data about patients was reached. Since the patient's past data could not be reached, no assessment could be made about whether the cases were new or old and the where the location of the disease involvement was.

\section{CONCLUSION}

In our study the data presented do not seem to suggest that is any increase or decrease in drug resistance over time. In our study, resistance to major anti-TB drugs was determined for INH, which was the highest drug resistance in the strains investigated. The lowest drug resistance was detected for EM. The results are compatible with previous studies in Turkey. We believe that it would be useful to take into account these resistance ratios against anti-TB drugs when planning the treatment of Tuberculosis in patients in our region. 


\section{ETHICAL DECLARATIONS}

Ethic Committee Approval: This research was approved by the "Atatürk University Faculty of Medicine Ethics Board of Clinical Research of " by decree no. 19 on 13.02.2019.

\section{Informed Consent: Informed Consent not needed}

Referee Evaluation Process: Externally peer-reviewed

Conflict of interest statement: The authors declare that they have no conflict of interest.

Finansal Disclosure: This research received no external funding

Authors' contributions: All of the authors declare that they have all participated in the design, execution, and analysis of the paper, and that they have approved the final version.

\section{REFERENCES}

1. Murray CJ, Ortblad KF, Guinovart C, et al. Global, regional, and national incidence and mortality for HIV, tuberculosis, and malaria during 1990 2013:a systematic analysis for the Global Burden of Disease Study 2013. Lancet. 2014;384(9947):1005-70.

2. Kyu HH, Maddison ER, Henry NJ, et al. The global burden of tuberculosis:results from the Global Burden of Disease Study 2015. Lancet Infect Dis. 2018;18(3):261-84.

3. Global tuberculosis report 2019. Geneva:World Health Organization;2019. Licence:CC BY-NC-SA 3.0 IGO. https://www.who.int/tb/publications/ global_report/en/

4. Republic of Turkey Ministry of Health, General Directorate of Public Health, Tuberculosis Diagnosis and Treatment Guidelines. Ministry of Health Publication No:1129, Ankara 2019.

5. Ozkara S. Extensive drug resistant tuberculosis(XDR-TB). Solunum Hastalıkları 2007;18(2):88-92.

6. Baylan O. Treatment of drug-resistant tuberculosis. Turkiye Klinikleri J Med Sci. 2012;32(3):788-804

7. Colijn C, Cohen T, Ganesh A, Murray M. Spontaneous emergence of multiple drug resistance in tuberculosis before and during therapy. PLoS ONE. 2011;6(3):e18327.

8. Sharma A, Hill A, Kurbatova E, et al. Estimating the future burden of multidrug-resistant and extensively drug-resistant tuberculosis in India, the Philippines, Russia, and South Africa:a mathematical modelling study. Lancet Infect Dis. 2017;17(7):707-15.

9. Artan C, Deniz E, Biraderoglu H, Atan A, Artan M. Evaluation of primer antituberculosis drug susceptibilities of Mycobacterium tuberculosis complex strains isolated from respiratory tract samples. ANKEM Derg. 2013;27(4):179-83.

10. Bektore B, Haznedaroglu T, Baylan O, et al. Investigation of extensive drug resistance in multidrug resistance tuberculosis isolates. Mikrobiyol Bul. 2013;47(1):59-70.

11. Esenkaya Tasbent F, Dogan M. Resistance rates of Mycobacterium tuberculosis complex strains to the primary anti-tuberculosis drugs in Konya province, Turkey. Türk Mikrobiyol Cem Derg. 2016;46(4);165-71.

12. Burak Selek M, Baylan O, Gorenek L. Investigation of first-line antituberculosis drug susceptibility testing of Mycobacterium tuberculosis complex isolates in a Training and Research Hospital among the 20102016 Years. Nobel Medicus Journal. 2019;15(2):40-6

13. Adane K, Ameni G, Bekele S, Abebe M, Aseffa A. Prevalence and drug resistance profile of Mycobacterium tuberculosis isolated from pulmonary tuberculosis patients attending two public hospitals in East Gojjam zone, northwest Ethiopia. BMC Public Health. 2015;15(1):572.

14. Lee HY, Lee J, Lee YS, et al. Drug-resistance pattern of Mycobacterium tuberculosis strains from patients with pulmonary and extrapulmonary tuberculosis during 2006 to 2013 in a Korean tertiary medical center. Korean J Intern Med. 2015;30(3):325-34.
15. He XC, Zhang XX, Zhao JN, et al. Epidemiological trends of drugresistant tuberculosis in China from 2007 to 2014:A retrospective study. Medicine(Baltimore). 2016;95(15):e3336.

16. Türkiye'de Verem Savaşı 2018 Raporu. Republic of Turkey Ministry of Health, General Directorate of Public Health:Ankara, 2018.

17. https://hsgm.saglik.gov.tr/depo/birimler/tuberkuloz_db/dosya/raporlar/ Turkiye_de_Verem_Savas_2018_Raporu_kapakl_.pdf

18. Maurya AK, Kant S, Nag VL, Kushwaha RA, Dhole TN. Trends of antituberculosis drug resistance pattern in new cases and previously treated cases of extrapulmonary tuberculosis cases in referral hospitals in northern India. J Postgrad Med. 2012;58(3):185-9.

19. Yu CC, Chang CY, Liu CE, Shih LF, Hsiao JH, Chen CH. Drug resistance pattern of Mycobacterium tuberculosis complex at a medical center in central Taiwan, 2003-2007. J Microbiol Immunol Infect. 2010;43(4):28590.

20. Aktas AE, Yigit N, Ayyildiz A, Bastopcu A. Comparison of the mycobacterium growth indicator tube method and the method of proportion for drug susceptibility testing of Mycobacterium tuberculosis. Eurasian J Med. 2014;46(2):96-101.

21. Hattori T, Kobayashi N, Nagai H, Chagan-Yasutan H, Telan E, Solante MB. Nationwide HIV-MDR-TB survey in Japan and collaborative study in the Philippines. Int J Mycobacteriol. 2016;5 Suppl 1(5):18-9.

22. Lisdawati V, Puspandari N, Rif'ati L et al. Molecular epidemiology study of Mycobacterium tuberculosis and its susceptibility to anti-tuberculosis drugs in Indonesia. BMC Infect Dis. 2015;15(1):366.

23. Solomon A, Beckert P, Haileamlak A et al. Drug resistance and population structure of $M$. tuberculosis isolates from prisons and communities in Ethiopia. BMC Infect Dis. 2016;16(1):687.

24. Akhtar AM, Arif MA, Kanwal S, Majeed S. Prevalence and drug resistance pattern of MDR TB in retreatment cases of Punjab, Pakistan. J Pak Med Assoc. 2016;66(8):989-93.

25. Ozmen E, Aslan A, Ucar M, Aydin H, Yilmaz A. Resistance Ratios of Mycobacterium tuberculosis complex strains isolated in Erzurum Regional Tuberculosis Laboratory against Major Antituberculosis Drugs. ANKEM Derg. 2017;31(2):53-8. 